\title{
Assessment of groundwater quality using Physico-chemical analyses of Sahel-Doukkala region
}

\author{
Ayoub Benmhammed ${ }^{1 *}$, Nezha Mejjad ${ }^{2}$, Abdelmourhit Laissaoui $^{3}$, Adil Elyahyaoui ${ }^{3}$, El mahjoub Chakir ${ }^{1}$, Nadia Ziad $^{4}$ \\ and Hamid Marah ${ }^{3}$ \\ ${ }^{1}$ Laboratoire Physique des Matériaux et Subatomique, Faculté des Sciences, Université Ibn Tofail, Kenitra, Morocco \\ ${ }^{2}$ Laboratoire de Géologie, Faculté des Sciences Ben M’Sik, Université Hassan II, Casablanca, Morocco. \\ ${ }^{3}$ Centre National de l'Energie, des Sciences et des Techniques Nucléaire. B.P. 1382 RP 10001, Rabat, Morocco \\ ${ }^{4}$ Ecole National des Sciences Appliquées, Université Ibn Tofail, Kenitra, Morocco.
}

\begin{abstract}
Water quality preservation represents one of the biggest challenges the world is facing nowadays. In Morocco, water quality decline is among the significant problems facing the country's water sector. Geographic Information System (GIS) is an effective and useful tool for interpreting, evaluating and displaying spatial data for water resources management. In order to assess the Physico-chemical characteristics of groundwater of the Sahel-Doukkala aquifers, water samples were collected from 50 points well distributed in the study area, analysed according to standard methods, and the results were interpreted using the geographic information system (GIS) technique. There was an important spatial variability in the studied parameters and element concentrations $\left(\mathrm{T}^{\circ}, \mathrm{pH}, \mathrm{EC}, \mathrm{Cl}^{-}, \mathrm{Ca}^{2+}, \mathrm{Mg}^{2+}, \mathrm{Sr}, \mathrm{B}\right.$ and $\mathrm{Na}^{+}$), revealing that the aquifers lithology, sea intrusion and the agriculture methods are the main factors influencing the water nature in the study area.
\end{abstract}

\section{Introduction}

Water quality degradation is among the most challenging issues the world is currently facing. The demographic expansion and the increasing demand for water resources for different purposes, including agriculture, industrial activities, and tourism, lead to the water resources depletion, especially with the climate change effects (short runoff season, less reliable water resource base, increase of water temperature, increase of water $\mathrm{pH}$ ) [1].

Under social, economic and environmental pressures on water resources, the water demand has grown in the last decades. According to Wada et al., 2016, the worldwide water demand has increased by $600 \%$ compared to the past 100 years. Whereas, in the recently published report of the United Nations World Water Development (WWRD), it was reported that about 6 billion peoples around the world would suffer from clean water scarcity by 2050 while the global water demand is estimated to increase by 20 to $30 \%$ per year in the next three decades [2].

In Morocco, the groundwater resources suffer from the nature of Moroccan climate (Dry and semi-dry climate) [3], climate change effect [4-6], anthropogenic pressures $[7,8]$, and the mismanagement of freshwater sources [9]. According to the World Bank report (2017), it is projected that urban water demand would increase by $60 \%$ to $100 \%$ in the biggest cities by 2050 . Many studies were carried out in order to assess the groundwater quality in Moroccan cities and regions

\begin{abstract}
* Corresponding author:Ayoub.benmed@gmail.com such as Hssaisoune [3, 10-12]. Sahel Doukkala is located in the central part of the Moroccan Atlantic Coast. This region knows steadily increasing water use, especially with the population expansion $[13,14]$ and the extensive pumping from aquifers, especially in the coastal fringe where almost all the agriculture activities are concentrated [15]. Consequently, the water resources in this region suffer from both overexploitation and quality decline due to human activities. In this context, the present work assesses the hydrochemical characteristics of groundwater of the Sahel Doukkala and reviews the change in its quality during the last decades by investigating the latest research work carried out in the studied area.
\end{abstract}

\section{Methods and Materials}

\subsection{Study area}

The Sahel Doukkala is a coastal region located in the provinces of Safi and El Jadida and subdivided into two large areas on the Sahel and Doukkala situated between latitudes $32^{\circ} 15^{\prime}$ and $33^{\circ} 15^{\prime}$ North and longitudes $8^{\circ}$ and $9^{\circ} 15^{\prime}$ covering an area of $7700 \mathrm{Km}^{2}$ with about $150 \mathrm{~km}$ of coastline. It is limited to the North and east by the wadiOumErRabia, to the west and in the North-West by the Atlantic Ocean, in the 
South by the base of the hills of Mouissate and in the South-East by the primary massif of Rehamna.

The climate in the Doukkala Sahel is semi-arid while the minimum temperature $\left(\mathrm{T}^{\circ}\right)$ is around $18^{\circ} \mathrm{C}$ in winter and maximum $\left(\mathrm{T}^{\circ}\right)$ is $23^{\circ} \mathrm{C}$ in summer. According to the El-Jadida station, the average yearly rainfall is $317 \mathrm{~mm}$, while the maximum rainfall was registered in December (59.8) [16].

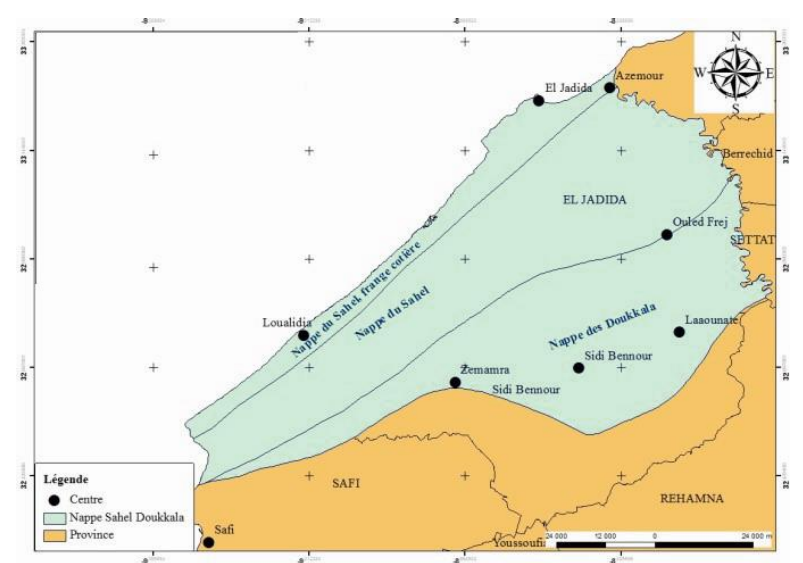

Fig.1.The geographical location of the studied area.

\subsection{Sampling and analysis:}

\subsubsection{Sampling}

A field mission was carried out in January 2013 in the Sahel of Doukkala, where 50 groundwater samples were collected through a selected sampling network to provide representative data on the term of spatial variability of groundwater quality in the study area.

To avoid the contamination of the sample, the water sampling was carried out by using Polyethylene bottles and gloves. The sampling collection was carried out according to Rodier's protocol [17]. Five water samples were collected at each sampling point and stored in five Polyethylene bottles for a different type of analysis.

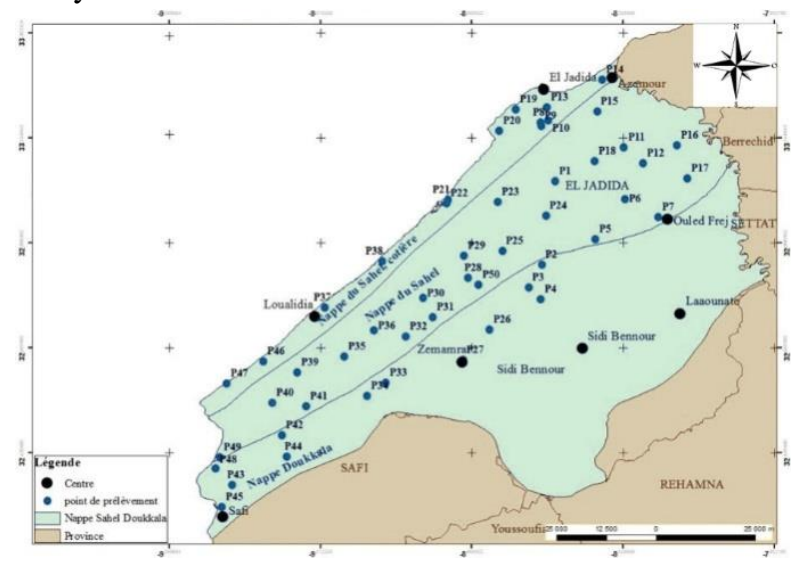

Fig.2. Sampling point locations.

\subsection{2 $\mathrm{T}^{\circ}, \mathrm{pH}$ and EC determination (in situ analysis)}

50 water samples were collected from 37 wells (P1, P3-P9, P12-P14, P16, P19, P21-P24, P27, P28, P30, $\mathrm{P} 32-\mathrm{P} 40, \mathrm{P} 42-\mathrm{P} 45, \mathrm{P} 47-\mathrm{P} 49)$ and 13 boreholes (P2, P10, P11, P15, P18, P20, P25, P26, P29, P31, P41, $\mathrm{P} 46, \mathrm{P} 50)$ and analysed in situ for determining $\left(\mathrm{T}^{\circ}, \mathrm{pH}\right.$, and Electrical Conductivity (EC)) immediately after collection and placed in a cooler $\left(2\right.$ to $4^{\circ} \mathrm{C}$ ) for a maximum of 72 hours before sending them to the laboratory for chemical analysis.

\subsubsection{Laboratory analysis}

The water samples were analysed by the Ion chromatography (IC) technique (type DIONEX). Cations such as calcium $\left(\mathrm{Ca}^{2+}\right)$, magnesium $\left(\mathrm{Mg}^{2+}\right)$, sodium $\left(\mathrm{Na}^{+}\right)$, potassium $\left(\mathrm{K}^{+}\right)$and anions such as bicarbonates $\left(\mathrm{HCO}^{3-}\right)$, chlorides $\left(\mathrm{Cl}^{-}\right)$, bromide $\left(\mathrm{Br}^{-}\right)$ and sulphates $\left(\mathrm{SO}_{4}{ }^{2-}\right)$ were measured in each water sample.

Bore and Strontium concentrations were determined by using the Inductively Coupled Plasma Mass Spectrometry (ICP-MS) in the laboratory of Unit climate and water at CNESTEN

Regarding the reliability of the results, we proceeded to apply the ionic balance (by taking into account the existing relationship between the total cations and the total anions) with an acceptable error margin of $10 \%$ $[18,19]$.

\subsubsection{GIS}

Modelling was performed in several steps. ArcGIS 10.7.1 was used as an effective tool for mapping and visualising the spatial distribution of groundwater quality parameters, understanding the natural environment and managing water resources.

\section{Results}

\subsection{Physical parameters}

\subsubsection{Temperature}

The water quality as a function of temperature is presented in figure 3 . The obtained values of temperature are ranged from 11,8 to 23,8 while the water quality varied between good and excellent. The samples retrieved from the NE part of the study area exhibit a good water quality, while the samples showed excellent water quality in the SW part. The samples retrieved from the coastal fringe showed good quality in the South and excellent quality (Wells: P37, P47, 
Borehole: P46) in the North (Borehole: P20, Wells: P19, P22, P38).

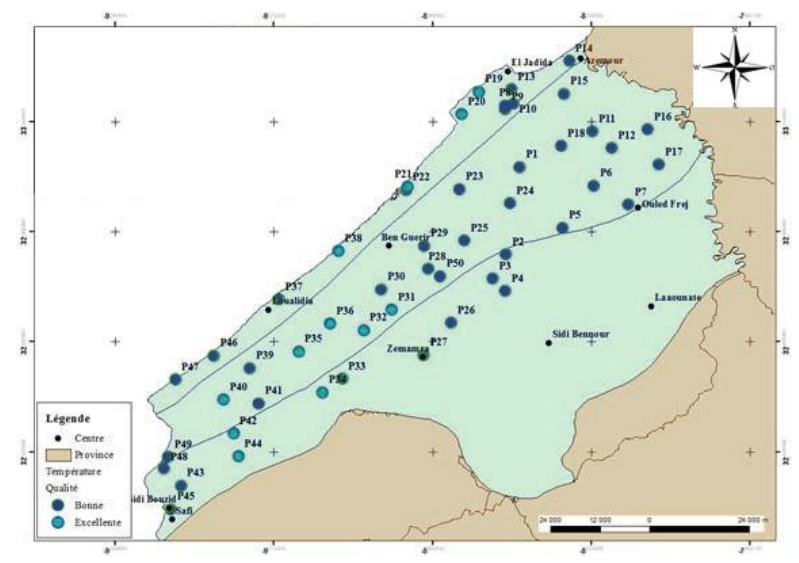

Fig.3. Spatial distribution of underground water temperature in the studied area.

\subsection{2 pH:}

The $\mathrm{pH}$ values are ranged from 6, 88, recorded in (P45) and 8, 44 (P14). The measured values of $\mathrm{pH}$ for almost all samples are corresponding to natural water where according to High Commission for Water and Forestry and the Fight Against Desertification [20], in natural waters, the $\mathrm{pH}$ is usually ranging between 6 and 8,5. The obtained values are in good accordance with the values measured in groundwater in the Sahel of Doukkala region during the wet season for samples retrieved between 2016 and 2018 [21]. Almost all the sampling point showed neutral water, while few samples are slightly alkaline located in the NW (P2, P4, P14, P16, P17, P19, P23, P38 and P44).

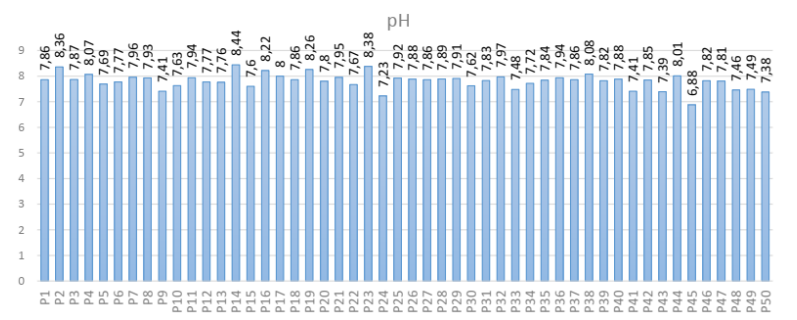

Fig.4. Measured $\mathrm{pH}$ for each water sample.

\subsubsection{EC}

Electrical conductivity is an excellent tracer of water origin, and it provides information about water mineralisation [20]. The maps $\mathrm{a}$ and $\mathrm{b}$ presented in Figure 5 show the values of EC in each water sample (Fig.5a) and the spatial distribution of EC all around the study area (Fig.5b). The values are relatively high in the NE (Sidi Bennour, Zemamra) and NW (downstream parts of Oued Oum Erabie and El Jadida city) and low in the SW part of the Sahel of Doukkala. As the EC reflects the degree of water salinity [22], the higher values recorded around El Jadida could be related to the marine intrusion resulting from the excessive pumping activities in good accordance with the findings reported in [23-26]. Given the distance of the Sahel basin from the sea, the higher values registered around Zemamra and Sidi Bennour are not necessarily associated with marine intrusion. However, they can be related to natural factors such as the flow direction and the concentration of dissolved salts [27] and/or to human activities.

a

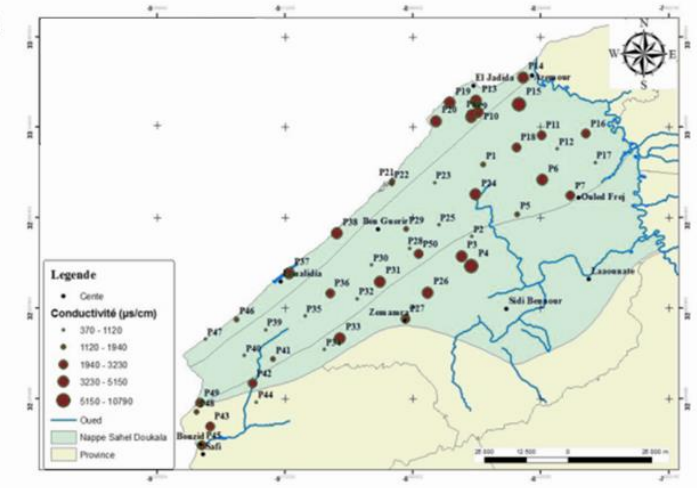

b

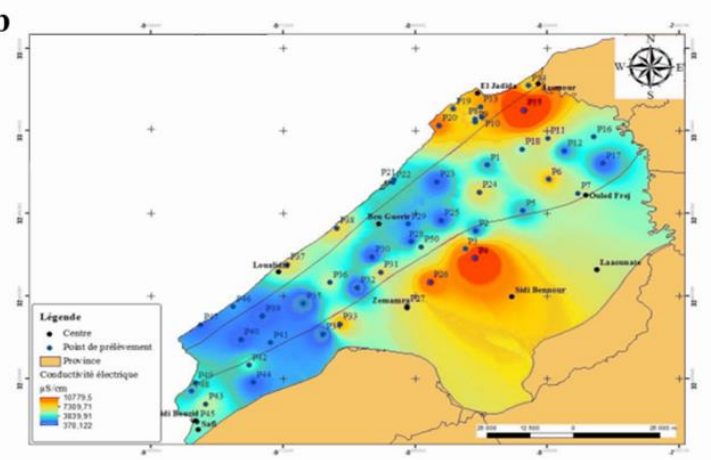

Fig. 5. (a) Values of EC measured in the 50 water samples; (b) spatial distribution of EC.

\subsection{Chemical analysis}

\subsubsection{Chloride and Sodium}

The spatial distributions of chloride $\left(\mathrm{Cl}^{-}\right)$and sodium $\left(\mathrm{NA}^{+}\right)$are presented in Figure 6. They display similar distribution as the EC. The highest values are shown in El Jadida near the coastal fringe and around SidiBennour and Zemamra. The $\mathrm{Cl}^{-}$values are ranged from $24,82 \mathrm{mg} / \mathrm{l}$ to $3658 \mathrm{mg} / \mathrm{l}$, while the maximal value was recorded in the North of the Sahel Doukkala aquifer (P15) (Fig.6.a). The Sodium concentrations varied between 12,91 mg/l and $1452 \mathrm{mg} / \mathrm{l}$ (Fig.6.b). The

The $\mathrm{Cl}-\mathrm{Na}$ stoichiometric diagram of Figure 7 indicated that much of the water samples displayed proportions close to 1:1 (into green ellipse), revealing that the molar release of $\mathrm{Cl}^{-}$and $\mathrm{Na}^{+}$to water comes exclusively from Halite dissolution $\left(\mathrm{NaCl}=>\mathrm{Na}^{+}+\mathrm{Cl}^{-}\right.$ ); however, samples with concentrations above 10 meq/L have a tendency of excess of $\mathrm{Cl}^{-}$over $\mathrm{Na}^{+}$. This tendency must be related to several factors but mainly to: (1) $\mathrm{Na}^{+}$sorption in aquifer fine materials (lime and clays) and/or (2) additional introduction of $\mathrm{Cl}^{-}$from the agriculture activities in the study area. Thus, the origin of salinity cannot be attributed to marine intrusion in the Sidi Bennour and Zemamra areas as the distance to 
the ocean exceeds $50 \mathrm{Km}$, but to the wastewater discharges used for irrigation $[28,29]$ and/or related to the process of water-aquifer interaction.
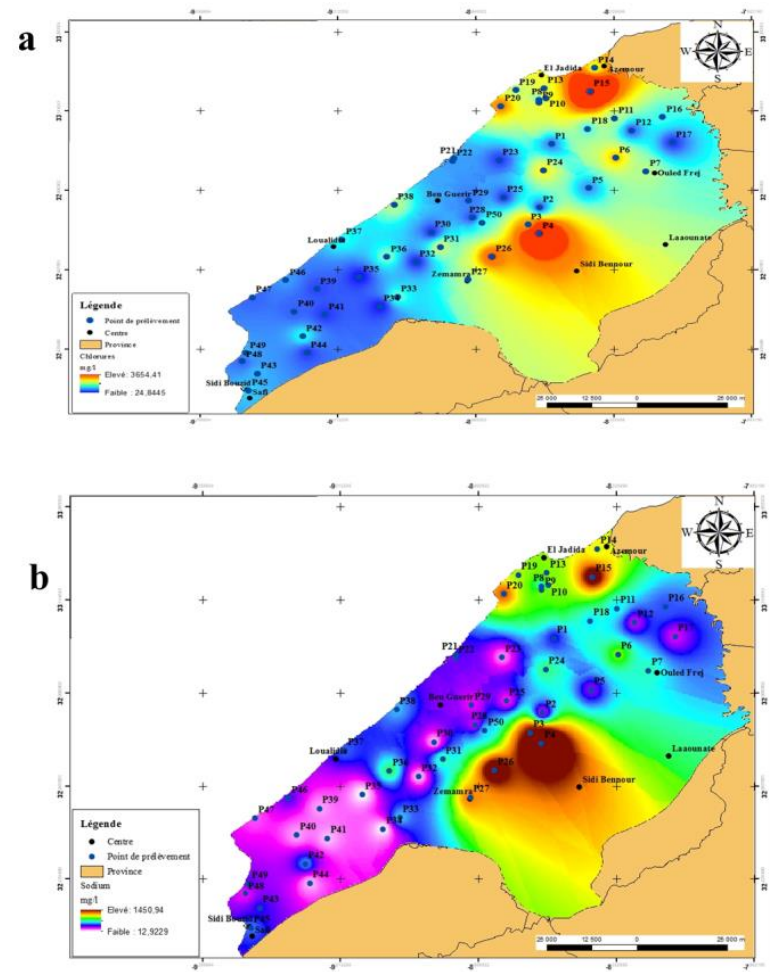

Fig.6. Spatial distribution of chloride $\mathrm{Cl}^{-}$(a) and $\mathrm{Na}^{+}$(b).

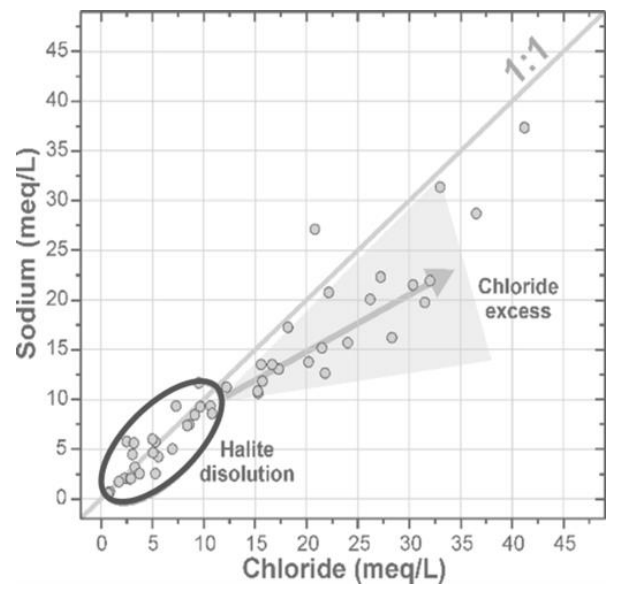

Fig.7. Hydrochemical graph of water samples (Chloride vs Sodium).

The chloride concentration in water can provide the type of water according to the classification of Stuyfzand [30]. The type of water for each sampling location is presented in Figure 8. The map indicates a wide variation of water from one location to another. The water type is mainly fresh and fresh-brackish, brackish and brackish-salt. Twenty-three samples present brackish water distributed primarily in the Sahel aquifer and the aquifer of the coastal Sahel, while the brackish-salt water is mainly concentrated in the Doukkala aquifer in good accordance with EC distribution (Fig.5.). These results indicate again that the higher salinity values found in the Doukkala aquifer distant from the ocean by $50 \mathrm{~km}$ is mainly related to other factors and not necessarily associated with the marine intrusion.

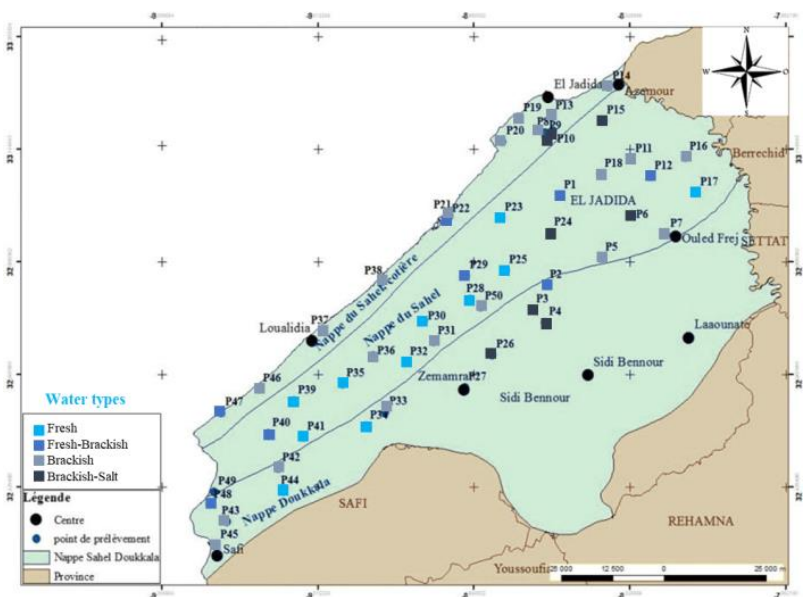

Fig.8. Map of water types distribution as revealed by Stuyfzand classification.

\subsubsection{Magnesium and calcium}

The spatial distribution of $\mathrm{Mg}$ and $\mathrm{Ca}$, are displayed in Figure 9. Both, $\mathrm{Ca}$ and $\mathrm{Mg}$ show similar spatial distribution indicative of the same origin linked to the nature of the dolomitic reservoir. The highest values are recorded in the North part of the coastal Sahel aquifer. The values of $\mathrm{Ca}$ and $\mathrm{Mg}$ ranged from 26.12 $\mathrm{mg} / \mathrm{L}$ (P17) to $896 \mathrm{mg} / \mathrm{L} \mathrm{(P15)} \mathrm{and} \mathrm{from} 1.98 \mathrm{mg} / \mathrm{L}$ (35) to $395 \mathrm{mg} / \mathrm{L}$ (P15), respectively.

According to Kaid Rassou [31]; the dissolution of the carbonate formations of the Cretaceous and Plioquaternary, calcite (CaCO3) and dolomite $\mathrm{CaMg}$ (CO3)2, and gypsiferous formations (CaSO4, 2H2O) of Jurassic are the main sources of these elements in the groundwater of this region.

The distribution of $\mathrm{Mg}^{2+} / \mathrm{Ca}^{2+}$ ratios values is displayed in the map of Figure 10. The values are inferior to 1 , indicating that there is enrichment by $\mathrm{Ca}$ over $\mathrm{Mg}$, which reflect the abundance of limestone facies on the dolomitic facies of the aquifers lithology as reported for the coastal basin of the Oualidia in Kaid Rassou, [31]. Approximatively, similar results were reported in Fadil 2014 [23], where the calculated $\mathrm{Mg}^{2+} / \mathrm{Ca}^{2+}$ ratios for wells distant from the ocean by $1 \mathrm{Km}$ were ranging from 0,10 to 1,05. Aris et al., 2012 [33] indicate that all ratios $\mathrm{Mg}^{2+} / \mathrm{Ca}^{2+}$ shown values higher than 0,7 designate a mixture of fresh and seawater. 

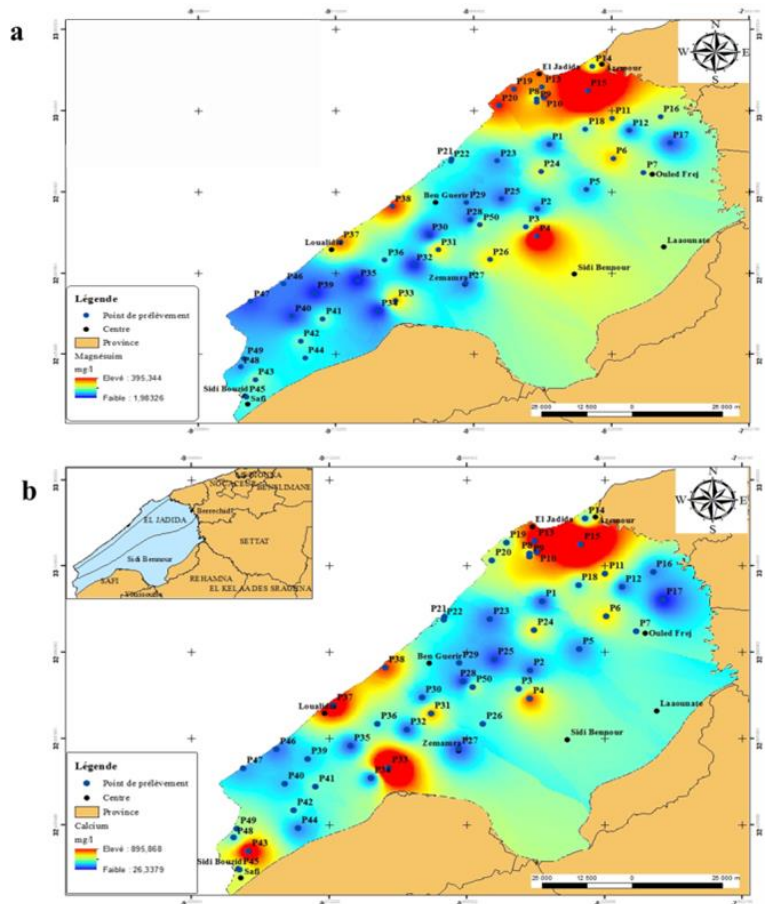

Fig.9. Spatial distribution of chloride $\mathrm{Mg}(\mathrm{a})$ and $\mathrm{Ca}(\mathrm{b})$.

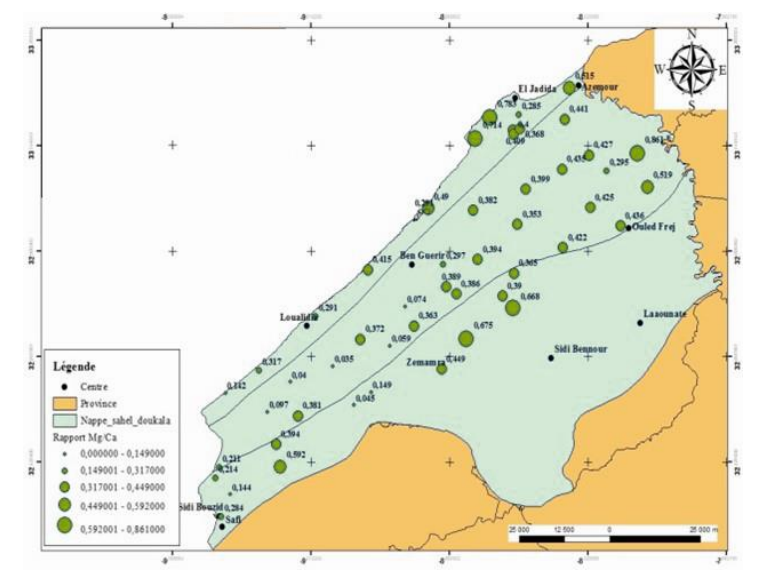

Fig.10. Spatial distribution of $\mathrm{Mg}^{2+} / \mathrm{Ca}^{2+}$ ratios.

\subsubsection{Water nature according to $\mathrm{Sr}$ and $\mathrm{B}$ concentrations}

Figure 11 shows two maps exposing the nature of water in each sample location according to the measured concentration of Strontium and Boron. For freshwater (f), brackish (b) and saltwater (S) the concentration of $\mathrm{Sr}$ and B for each type are as follow [34]:

$$
\begin{aligned}
& \text { Sr }(\mu \mathrm{g} / \mathrm{l}): \text { (f) }>1600 \text {; (b) 1600- 5000; (S) }<5000 \\
& \text { B }(\mu \mathrm{g} / \mathrm{l}): \text { (f) }>200 \text {; (b) 200- 500; (S) }<500
\end{aligned}
$$

The nature of water fluctuates between fresh and brackish in the Sahel aquifer, fresh in the South of Sahel aquifer, Doukkala aquifer and coastal Sahel aquifer, while in the centre of Doukkala aquifer, the water nature is salty in good accordance with chloride results and EC. The North of the Sahel and Doukkala aquifers indicate saltwater according to strontium values and brackish according to the $\mathrm{B}$.

The Strontium is an indicator of evaporates, while the calcium is an indicator of marine inputs. The calculated ratios of $\mathrm{Sr}^{2+} / \mathrm{Ca}^{2+}$ were mapped and presented in Figure 12. The Strontium shows strong enrichment over calcium in almost all sampling locations in the coastal Sahel and Sahel aquifers, where the values of the ratios were $>1$. Some ratios show values $<1$ observed in the centre of the Sahel aquifer. The obtained results are in good accordance with the analysis done in the Oualidia lagoon sediments, where a strong enrichment of Strontium over calcium was reported in Mejjad 2020 [35]. The same findings were found in the groundwater of the Oualidia Sahel aquifer, where the examination of the $\mathrm{rSr}^{2+} / \mathrm{rCa}^{2+}$ ratios have exhibited obvious contamination by evaporates (the Jurassic evaporate deposits); in KaidRassou 2005 [31]).
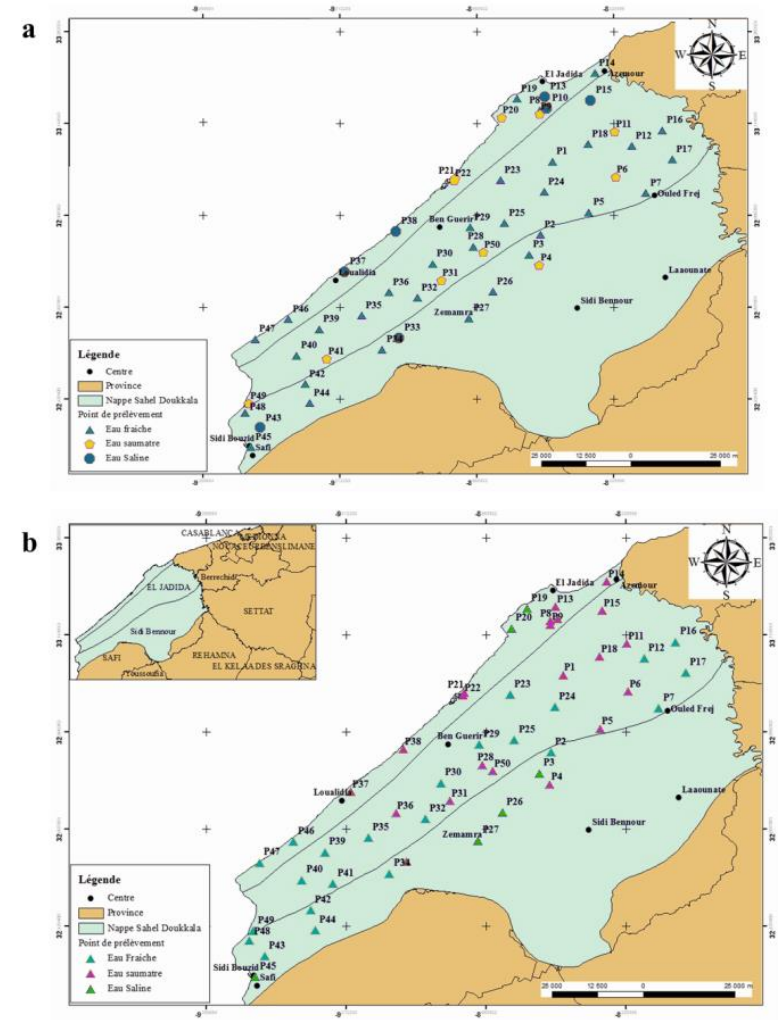

Fig.11. Water nature according to $\mathrm{B}$ (a) and $\mathrm{Sr}$ (b) concentrations.

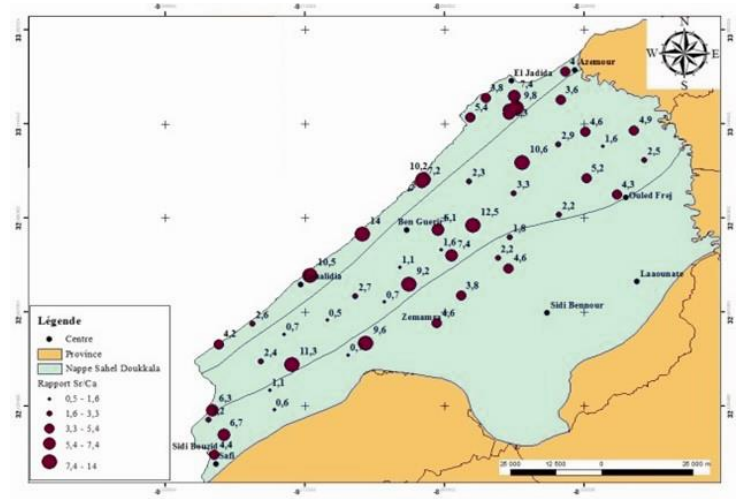

Fig. 12. $\mathrm{Sr}^{2+} / \mathrm{Ca}^{2+}$ ratios calculated for each water sample.

Figure 13 shows a comparison between water temperature and boron concentrations and electrical conductivity and Boron. The Temperature-Boron plot indicates a profound source of mineralisation from the bottom of the aquifer as the Boron is usually released from deep groundwater and ancient aquifers [36] being highly mineralised [37]. Also, the higher $\mathrm{T}^{\circ}$ reflects deeper water as it was reported that in deep wells, 
the $\mathrm{T}^{\circ}$ of water generally rises $1^{\circ} \mathrm{F}$ for every 60 feet to 100 feet of deepness [37]. Thus, a significantly positive correlation observed between $\mathrm{T}^{\circ}$ and $\mathrm{B}$, suggesting the presence of a deeper source of water highly mineralised.
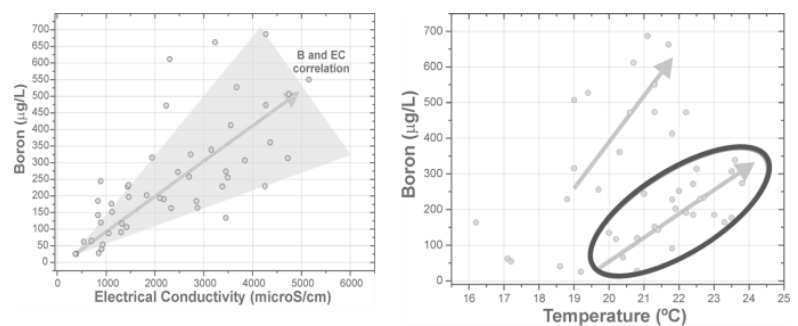

Fig.13. Hydrochemical graphs of water samples taking in the study area for Electrical conductivity vs Boron and temperature vs Boron.

\section{Conclusions}

The analyses show that the water is highly mineralised and provide a clear picture of the causes influencing the water type in the Sahel and Doukkala aquifers.

The aquifers lithology, sea intrusion and different human activities (agriculture, farms and urban areas) are among the factors influencing the water nature in the study area.

It must be added that these analyses highlight the need for implementing projects management and integrated land use planning to conserve and protect this natural resource.

\section{References}

1. Richard M. Adams, and Dannele E. Peck. "Effects of Climate Change on Water Resources." Choices, vol. 23, no. 1, JSTOR, pp. 12-14. (2008)

2. World Water Assessment Programme (Nations Unies), The United Nations World Water Development Report 2018 (United Nations Educational, Scientific and Cultural Organization, New York, United States) www.unwater.org/publications/world-waterdevelopment-report-2018/. (2018).

3. H, ssaisoune M, Bouchaou L, Sifeddine A, Bouimetarhan I, Chehbouni A. Moroccan Groundwater Resources and Evolution with Global Climate Changes. Geosciences.; 10(2):81 (2020).

4. D. El Hafid, Z. Zerrouqi, B. Akdim. Etude des sequences de secheresse dans le basin d'isly (Maroc oriental). larhyss journal, research laboratory in subterranean and surface hydraulics, 31, pp.83-94. (2017) ffhal-01773209f

5. Driouech, F., Déqué, M., Mokssit, A. Numerical simulation of the probability distri-bution function of precipitation over Morocco. Climate Dynamics 32, 10551063 (2009)

6. Stour, et Agoumi, Climatic drought in Morocco during the last decades, Hydroécol. Appl.Volume 16, 215 - 232 (2008)

7. Y. Asfers, H. Taouil, H. Hanafi, S.Elanza, S. Ibn Ahmed, M. Aboulouafa,Study of the Sediments Metallic Contamination in OumEr-RbiaEstuary,Journal of Applied
Chemistry,2278-5736.Volume 10, Issue 1 Ver. I, PP 6775( 2017)

8. A.ElOualiLalami, M.Merzouki, O. El Hillali, S. Maniar, S. Ibnsouda Koraichi, pollution des eaux de surface de la ville de fes au maroc: typologie, origine et consequences , larhyss journal N09, (2011)

9. Wright, Elliese, "An Investigation into Morocco's Water Crisis". WWU Honors Program Senior Projects. 358. (2020)

10. Kanga, I.S., Naimi, M. \&Chikhaoui, M. Groundwater quality assessment using water quality index and geographic information system based in Sebou River Basin in the North-West region of Morocco. Int J Energ Water Res 4, 347-355 (2020).

11. Kanga, I. S., Chikhaoui, M., \&Naimi, M. Water quality assessment using a new proposed water quality index: a case study from Morocco. International Journal of Environment, Agriculture and Biotechnology, 4(4), 957792. (2019b).

12. Boujghad, A., Bouabdli, A. \& Baghdad, B. Groundwater quality evaluation in the vicinity of the DraaSfar Mine in Marrakesh, Morocco. Euro-Mediterr J Environ Integr 4, 12 (2019).

13. EkoueleMbaki V. R., Boukdir A., MengaOkandza P., El Mahboul A., Hilali M., Zitouni A. Quantitative Analysis of the water potential in the region of Sahel Doukkala (Morocco). Journal of Water Sciences \& Environment Technologies,(2016).

14. Soudi B, Rahoui M, Chiang C, Badraoui M, Aboussaleh A Eléments méthodologiques de mise en place d'un système de suivi et de surveillance de la qualité des eaux et des sols dans les périmètres irrigués. Hommes Terre et eaux 29(111) : 13-22,(1999) .

15. Fadili, A. Etude hydrogéologique et géophysique de l'extension del'intrusion marine dans le sahel de l'Oualidia (Maroc) :Analyse statistique, hydrochimie et prospectionélectrique. Thèse de Doctorat. Univ. ChouaïbDoukkali, Fac. Sci. El Jadida, Morocco. 2014.

16. DMN.CNRM. Equipe Climatologie et Banque de Données, Direction de la Météorologie Nationale (2005).

17. Rodier J. L'analyse de l'eau : Eaux naturelles, eauxrésiduaires, eaux de mer. Edition Dunod Paris. (1984).

18. Rodier, J.. L'analyse de l'eau. 9ème édition. DUNOD, Paris, France (2009).

19. Domenico, P. A. and Schwartz, F.W. Physical and Chemical Hydrogeology. Vol. 1, Wiley, pp. 506 (1998).

20. Haut-Commissariat Aux Eaux et Forêt et la Lutte Contre la Désertification (HCEFLCD). Etude sur la pisciculture au barrage Almassira, CR dar CHAFAAI, Cercle d'ELBROUGE, Province de Settat. p.201 (2006).

21. EL Adnani. I, Younsi. A, Ibno Namr. K, El Achheb. A and Irzan. E, Assessment of Seasonal and Spatial Variation of Groundwater Quality in the Coastal Sahel of Doukkala, Morocco , Nature Environment and Pollution Technology Vol. 19 N1 pp. 17-28 (2020).

22. Meybeck, M. and Helmer, R. The quality of rivers: from pristine state to global pollution. Paleogeog. Paleoclimat. Paleoecol. (Global Planet. Change Sect.), 75, 283-309. (1989)

23. Fadili, A. Etude hydrogéologique et géophysique de l'extension de l'intrusion marine dans le sahel de l'Oualidia (Maroc) :Analyse statistique, hydrochimie et 
prospectionélectrique. Thèse de Doctorat. Univ. ChouaïbDoukkali, Fac. Sci. El Jadida, Morocco. (2014)

24. Fakir, Y.. Caractérisation hydrogéologique et hydrochimique des aquifères côtiers du Sahel de Safi à Oualidia (Méséta côtière- Maroc).Thèse 3éme cycle. Univ. Cadi Ayyad, Marrakech, pp. 143. (2001)

25. Fakir, Y. and Razack, M.. Hydrodynamic characterisation of a Sahelian coastal aquifer using the ocean tide effect (Dridrate Aquifer, Morocco (2003)

26. El Achheb, A.. Contribution à l'étude de la minéralisation et identification des sources de contaminations des eaux souterraines, application au système aquifère du Bassin Sahel Doukkala (Maroc). Thèse d'état, UnivChouaïbDoukkali, El Jadida, pp. 206. (2002)

27. Bermond R. et Perrdon C. Paramètres de la qualité des eaux. Ministère de l'environnement Paris, 259 (1979).

28. Doumali.K and IbnoNamr.K, The Assessment of Soil Quality in the Irrigated Area in the Perimeter LowService of Doukkala for the Two Lockers SidiBennour and SidiS'mail in Morocco, journal of Life Sciences 7 195-201 (2018)

29. Lhadi, E.K., Mountadar, M., Younsi, A., Martin, G., Morvan, J.,. Pollution par les nitrates des eaux souterraines de la zonelittorale de la province dÕEl Jadida (Maroc). Revue dÕhydrogéo-logie, BRGM 3, 21-33. (1996)

30. Stuyfzand, P. J. A new classification of groundwaterand application to the coastal dune aquifer system in theNetherlands. Proceed. Of the 9th Salt Water IntrusionMeeting, Delft, 641-655. (1986).

31. K. KaidRassou, Y. Fakir, M. Bahir, K. Zouari, M. Marah ,Origine et datation des eaux souterraines du bassin hydrologique de lagune d'Oualidia. Estudios Geol., 61: 191-196 (2005)

32. Younsi.A, Mania.J, Lhadi E. K et Mudry J, Influence of extreme rainfall events on an unconfined coastal aquifer (Chaouia, Morocco), Revue des sciences de l'eau Journal of Water Science, Volume 14, numéro 2, (2001)

33. Aris AZ, Praveena SM, Abdullah MH, Radojevic M. Statistical approaches and hydrochemical modelling of groundwater system in small tropical island. J Hydroinform 14(1):206-220 (2012)

34. Saxena.K.V, Rajput.S, Singh.V. S, Occurrence, Behavior and Speciation of arsenic in groundwater, Current Science 86(2) (2004)

35. Mejjad, N., Laissaoui, A., Fekri, A., ...Benkdad, A., Amsil, H, Tracking natural and human impact on sediment dynamics using radiometric approach in Oualidia lagoon (Morocco), International Journal of Environmental Analytical Chemistry, (2020)

36. Warner, K.L. Analysis of nutrients, selected inorganic constituents, and trace elements in water from Illinois community-supply wells, 1984-91. U.S. Geological Survey Water-Resources Investigations Report 99-4152. (1999)

37. The above information is excerpted in large part from Chapter 23 of the 1999 NGWA Press publication, Ground Water Hydrology for Water Well Contractors. 